\title{
The Effectiveness of The Use of The "Kartubarpel" Media in Learning Calistung Mentally Disabled Children Based on Learning to Play in "Tunas Kasih" SLB Lidah Kulon Surabaya
}

\author{
Wahyu Widayati ${ }^{1}$, Viktor Sagala ${ }^{2}$, Sri Utami $^{3}$, Ardianik $^{4}$ \\ \{wahyu.widayati@unitomo.ac.id ${ }^{1}$, viktor.sagala@unitomo.ac.id ${ }^{2}$, sri.Utami@unitomo.ac.id ${ }^{3}$ \} \\ ${ }_{1,2,3,4}$ Universitas Dr. Soetomo, Indonesia
}

\begin{abstract}
The use of learning media is very helpful in learning activities, especially for children with special needs (ABK), especially mentally disabled children. The purpose of this paper is to describe the effectiveness of reading, writing and counting (CALISTUNG) learning media for mentally retarded children learning while playing at SLB Tunas Kasih Lidah Kulon Surabaya. The research method used in this paper is literature research, whose data is sourced from reports on the results of research on the development of learning media. The research was conducted at the Surabaya Tunas Kasih Lidah SLB and the results were reported to the Unitomo Research Institute Surabaya. KARTUBARPEL media the results of the development have been declared suitable for use as a medium of reading, writing and counting for mentally retarded children. The effectiveness of the use of learning media is calculated based on the percentage of children who are highly interested and the percentage increase in children's cognitive abilities after learning using the media. The props are in the form of syllable cards, word cards, picture cards, dominoes, and snake ladders. The mean increase in the value of reading, writing and counting from pretest to posttest was 26.2, 10.1 and 12.0 respectively. The average effectiveness of the three learning media is $51 \%$. Thus, it can be concluded that reading, writing and arithmetic teaching aids (CALISTUNG) can be used, provided that further development is needed, in order to achieve higher effectiveness. This media is also useful for developing other abilities such as listening, social emotional, and fine motor skills because it is applied with a learning model while playing. This media can also be applied to learning various other themes and sub-themes.
\end{abstract}

Keywords: Media, calistung, mental retardation.

\section{Introduction}

The use of learning media is very helpful in learning activities, especially for children with special needs $(\mathrm{ABK})$, especially mentally disabled children. The purpose of this paper is to describe the effectiveness of calistung learning media for mentally retarded children learning while playing at SLB Tunas Kasih Lidah Kulon Surabaya. Reading, writing, counting is one of the most important activities in life and it can be said that all learning processes are based on reading skills. Impotence is a term used to refer to a child who has an intellectual level below the average. There are three categorizations for mentally retarded children, namely (a) Mild mental retardation; Their level of intelligence (IQ) ranges from 50-70. (b) Moderate mental retardation; their intelligence level ranges from 30-50. (c) Heavy mental impairment; Their level of intelligence (IQ) is below 30. Today the media has different functions in the 
field of education and training. The benefits include helping in delivering the contents of subject matter, practice or both. This media is known as the cartubarpel learning media. The advantages of kartubarpel media for mentally retarded children is that this media can accommodate students who are slow to receive learning, because it can provide a more affective climate in a more individualized way, never forget, never be bored, very patient in learning calistung as desired.

Several relevant studies have previously been conducted by previous researchers, including Diwangkara et al. [1] which are computer-based. The results obtained in the form of interactive learning media applications that can be installed on a computer or laptop device and are able to display animation how to read and write. This research is based on Computer Assisted Instruction. Then Johanes' research, et al. [2] is the development of audiovisual media in rough motoric learning in mildly mentally retarded children. This study produced audiovisual media in gross motor learning in mentally retarded children. Furthermore, the research of Widayati and Utami [3] concerning the Development of Reading Materials, Writing Beginning with the "Syllable" method for Early Childhood ". This study resulted in the learning process of Beginning Writing Reading (MMP) with syllable methods beginning with the introduction of syllables, such as /ba, bi, bu, be, bo/; /ca, ci, cu, ce, co/; /da, di, du, de, do/; /ka, ki, ku, ke, ko/, ect. These syllables are then combined into meaningful words. For example, from the syllabary list, the teacher can make various variations of syllable into meaningful words, for MMP teaching materials. This research is different from some of these studies. This research develops calistung learning media called "Kartubarpel" which is used when learning while playing, while other studies are only read and write. Besides that the media developed in this study is simpler and easier to make, so that the teacher can easily make and operate it is also not difficult. Another difference is the use of instructional media applied with learning while playing models. This is adjusted to the state of mentally retarded children who generally if they are easily drowsy. If it is applied with a learning model while playing, they will not get sleepy because of playing.

Reading and writing is one of the most important activities in life and it can be said that all learning processes are based on reading skills. Reading is a complicated activity that involves many things, not only reciting writing, it also involves visual activity, thinking, psycholinguistics, and metacognitive. The learning process of Beginning Writing Reading (MMP) with syllable methods begins with the introduction of syllables, such as bi /ba, bi, bu, be, bo/; /ca, ci, cu, ce, co/; /da, di, du, de, do/; /ka, ki, ku, ke, ko/, ect. These syllables are then combined into meaningful words. For example, from the syllabary list, the teacher can make various variations of syllable into meaningful words, for MMP teaching materials [4]. The syllable method is very effective for early childhood learning. The IQRO method is a preliminary reading method that is very good for children who are just learning to read. This method is very effective for improving initial reading skills [4].

Writing is to reduce or describe graphic symbols that describe a language understood by someone, so that other people can read the symbol of the graph if they understand the language and description of the graph. Beginning writing is a type of writing taught at the first and second grade level of elementary school. Beginning writing takes precedence over letter recognition and its position and function in words and sentences [5]. So, the beginning of writing is to describe graphic symbols in written form that require concentration, visual, cognitive, and motoric power activities. The ability to write is one type of writing language skills that are productive. The ability to write means that it can produce writing with various requirements from the way to write to the choice of words, and the rules of language that must be understood by the writer. Counting is doing counts can add, subtract, multiply and divide. 
There are various ways you can use to teach counting. One way is to count with money, introduce with numbers and practice memorizing numbers [6].

Children with Special Needs are children who have their own uniqueness in their types and characteristics, which distinguishes them from normal children in general. According to Sumekar [7], children with special needs are "children who experience irregularities, abnormalities or disabilities in terms of physical, mental, emotional and social, or from a combination of these things in such a way that they need special educational services adjusted for their deviations, abnormalities, or dispositions. Mentally retarded or mental retardation, is a term known to those who have mental retardation. According to the American Association on Mental Deficiency [7], mental retardation is called an inability of intellectual function, generally sluggish, namely having an IQ of less than 84, appearing before the age of 16 years, and accompanied by obstacles in adaptive behavior. Characteristics of mild mentally retarded children include a) Tend to have ability, b) concrete thinking and difficult thinking, c) Having difficulty in concentration, d) Ability to have limited socialization, e) Not able to store difficult instructions, f) Less able to analyze and assess events faced, g) The highest achievement in the field of reading, writing, and calculating the normal equivalent of grade III-IV children of primary school.

Children with Special Needs are children who have their own uniqueness in their types and characteristics, which distinguishes them from normal children in general. According to Sumekar [7], children with special needs are "children who experience irregularities, abnormalities or disabilities in terms of physical, mental, emotional and social, or from a combination of these things in such a way that they need special educational services adjusted for their deviations, abnormalities, or dispositions. Mentally retarded or mental retardation, is a term known to those who have mental retardation. According to the Ministry of National Education [8] the goals of fine motor development include 1) able to function smooth muscles (small) such as finger movements, 2) able to coordinate eye and hand accuracy, 3) able to control emotions. Meanwhile the function of fine motor development includes 1) as a tool for developing second-hand motion skills, 2) as a tool for increasing finger movements, 3) as a tool for training emotional mastery.

The function of learning media [6], namely: a) Attracting children's attention, b) Helping to accelerate understanding in the learning process, c) Clarifying the delivery of messages so as not to appear verbalistic, d) Learning more communicative and interactive, e) Eliminating children's boredom in learning, f) Increasing children's learning motivation in learning something, g) Increasing the level of children's involvement in learning activities.

\section{Research Method}

The research method used in this paper is literature research, whose data is sourced from reports on the results of research on the development of learning media. The research was conducted at the Surabaya Tunas Kasih Lidah SLB and the results were reported to the Unitomo Research Institute Surabaya. The research method in the report is Research and Development, with 4-D step (four D models), as explained by Soegiono [9], defining, designing, developing, and spread (disseminate). The teaching aids or media for reading, writing and arithmetic that have been developed consist of five components, namely letter boxes, barpel cards, line boxes, and snake ladder games. A barpel card consists of a domini card number, a syllable card. Snakes and ladders are equipped with cubes. 


\section{Research Results}

The results of the study indicate that the developed learning media have undergone a unity of validity and are declared feasible to use. However, in this paper, the focus is on the effectiveness of the media that has been developed. The effectiveness referred to in this case is calculated based on the increase in the value of students from pretest to post-test compared to the maximum increase which is ideally achieved after the application of calistung media. The formula for calculating effectiveness can be given as follows;

$$
\begin{aligned}
& E_{i}=\frac{N_{1 i}-N_{O i}}{100-N_{O i}} \\
& E=\frac{\sum E_{i}}{N}
\end{aligned}
$$

Where $\mathrm{N}_{\mathrm{oi}}=$ the first child pretest value, $\mathrm{N}_{1 \mathrm{i}}=\mathrm{i}$-child posttest value

$\mathrm{E}_{\mathrm{i}}=$ average activity based on $\mathrm{N}$ subject.

Table 1 Results Recapitulation

N subject.

Table 1. Results Recapitulation of Pretest and Posttest Value of Tuna graphite children

\begin{tabular}{cccccccccc}
\hline \multirow{2}{*}{ Subject } & \multicolumn{3}{c}{ Pretest } & \multicolumn{3}{c}{ Postest } & \multicolumn{3}{c}{ Increase in value } \\
\cline { 2 - 10 } & Reading & Writing & Counting & Reading & Writing & Counting & Reading & Writing & Counting \\
\hline 1 & 75.0 & 66.7 & 59.0 & 93.8 & 88.1 & 68.2 & 18.8 & 21.4 & 9.2 \\
2 & 68.8 & 69.1 & 61.2 & 100.0 & 76.2 & 75.2 & 31.2 & 7.1 & 14.0 \\
3 & 71.9 & 57.1 & 59.8 & 100.0 & 61.9 & 69.1 & 28.1 & 4.8 & 9.3 \\
4 & 71.9 & 66.1 & 54.9 & 100.0 & 80.9 & 73.6 & 28.1 & 14.8 & 18.7 \\
5 & 68.8 & 66.7 & 68.2 & 93.8 & 69.1 & 80.1 & 25.0 & 2.4 & 11.9 \\
\hline average & 71.3 & 65.14 & 60.62 & 97.52 & 75.24 & 73.24 & 26.24 & 10.1 & 12.62 \\
\hline
\end{tabular}

Based on table 1 and applying the formulas (1) and (2), effectiveness is obtained as shown in table 2 below.

\begin{tabular}{|c|c|c|c|c|c|c|c|c|c|c|}
\hline \multirow{3}{*}{$\frac{\text { Subject }}{1}$} & \multicolumn{3}{|c|}{ Increase in value } & \multicolumn{6}{|c|}{ Efektifitas } & \\
\hline & \multirow{2}{*}{$\frac{\text { Reading }}{18.8}$} & \multirow{2}{*}{$\frac{\text { Writing }}{21.4}$} & \multirow{2}{*}{$\begin{array}{r}\text { Counting } \\
9.2\end{array}$} & \multicolumn{2}{|c|}{ Reading } & \multicolumn{2}{|c|}{ Writing } & \multicolumn{3}{|c|}{ Counting } \\
\hline & & & & 75.2 & $\%$ & 64.3 & $\%$ & 22.4 & $\%$ & \\
\hline 2 & 31.2 & 7.1 & 14.0 & 100.0 & $\%$ & 23 & $\%$ & 36.1 & $\%$ & \\
\hline 3 & 28.1 & 4.8 & 9.3 & 100.0 & $\%$ & 11.2 & $\%$ & 23.1 & $\%$ & \\
\hline 4 & 28.1 & 14.8 & 18.7 & 100.0 & $\%$ & 43.7 & $\%$ & 41.5 & $\%$ & \\
\hline 5 & 25.0 & 2.4 & 11.9 & 80.1 & $\%$ & 7.21 & $\%$ & 37.4 & $\%$ & \\
\hline average & 26.24 & 10.1 & 12.62 & 91.1 & $\%$ & 29 & $\%$ & 32.1 & $\%$ & 51 \\
\hline
\end{tabular}

Table 2. Effectiveness of Using Teaching Aids on Ability to Read, Write and

Based on table 2, it is found that the average increase in the value of reading, writing and counting is $26.24,10.1$, and 12.62 respectively. The average effectiveness of learning media on the value of reading, writing and counting is $51 \%$. So, the use of calistung learning media using syllable cards, word cards, picture cards, dominoes, and snakes and ladders playing media has an effective enough for learning to read, write dan berhitung bagi anak tunagrahita, dengan berbasis kepada belajar sambil bermain. 


\section{Conclution}

Based on the results of the research and discussion in the previous chapter, conclusions can be drawn as follows: The average effectiveness of learning media on the value of reading, writing and counting is $51 \%$. So, the use of calistung learning media using syllable cards, word cards, picture cards, dominoes, and snakes and ladders playing media has sufficient effectiveness for reading, writing and counting for mentally retarded children, based on learning while playing.

\section{Reference}

[1] S. Diwangkara, "Pengembangan Media Pembelajaran Interaktif 3 Dimensi Baca Tulis untuk Anak Tunagrahita (Studi Kasus: TK Triamerta Singaraja)," J. Karmapati, vol. 5, no. $1,2016$.

[2] Johanes, "Pengembangan Media Audiovisual dalam pembelajaran Motorik Kasar pada Anak Tunagrahita ringan," J. Keolahragaan, vol. III, pp. 6-11, 2016.

[3] W. Widayati, V. Sagala, and S. Utami, "Pengembangan Media Pembelajaran Calistung Untuk Anak Tuna Grahita Berbasis Belajar Sambil Bermain Di Slb 'Tunas Kasih' Lidah Kulon Surabaya," 2019.

[4] W. Widayati and S. Utami, "Pengembangan Metode Membaca Permulaan dengan Metode IQRO untuk Anak Usia PAUD," in Prosiding Penelitian DIPA Universitas Dr. Soetomo Surabaya Tahun 2016., 2016.

[5] Muchlisoh, Pembelajaran Menulis Permulaan. Bandung: Angkasa, 1992.

[6] M. Montessori, Metode dan Media Pengajaran:Panduan Wajib untuk Guru dan Orang Tua Didik PAUD, Terjemahan. Yogyakarta: Pustaka Pelajar, 2013.

[7] Sumekar, Anak Tunagrahita. Yogyakarta: CV Karyono, 2012.

[8] Depdiknas, Pedoman Pelatihan: Lebih Jauh Tentang Sentra dan Soal Lingkaran. Jakarta: Direktorat Pendidikan Anak Usia Dini Dirjen PLS dan Pemuda, 2011.

[9] Soegiono, Pedoman Penelitian Pendidikan. Jakarta: Rineka Cipta, 2009. 